\title{
Terpene Composition of Three Species of Gymnosperms from Vietnam
}

\author{
Do N. Dai ${ }^{1}$, Tran D. Thang ${ }^{2 *}$, Isiaka A. Ogunwande ${ }^{3^{*}}$ \\ ${ }^{1}$ Faculty of Biology, Vinh University, Vinh City, Vietnam; ${ }^{2}$ Faculty of Chemistry, Vinh University, Vinh City, Vietnam; ${ }^{3}$ Natural \\ Products Research Unit, Department of Chemistry, Faculty of Science, Lagos State University, Lagos, Nigeria. \\ Email: *thangtd@vinhuni.edu.vn, ${ }^{*}$ isiaka.ogunwande@lasu.edu.ng
}

Received June $15^{\text {th }}, 2013$; revised July $15^{\text {th }}, 2013$; accepted August $19^{\text {th }}, 2013$

Copyright (C) 2013 Do N. Dai et al. This is an open access article distributed under the Creative Commons Attribution License, which permits unrestricted use, distribution, and reproduction in any medium, provided the original work is properly cited.

\begin{abstract}
In the present investigation, we studied new essential oil contents and compositions of three individual plants from $\mathrm{Cu}-$ pressaceae family cultivated in Vietnam. The air-dried plants were hydrodistilled and the oils analysed by Gas chromatography (GC) and Gas chromatography couples with Mass spectrometry (GC-MS). The components were identified by comparison of their retention indices on HP-5 MS capillary column with literature reference and MS pattern with authentic library's collection. $\alpha$-Pinene (36.0\%), $\alpha$-cedrol (18.3\%) and thujopsene (5.7\%) were the main constituents of Cupressus tonkiensis Silba. Monoterpenes were the quantitative significant compounds of Sabina chinensis (L.) Antoine. These are bornyl acetate (19.5\%), sabinene $(17.3 \%)$ and $\alpha$-pinene $(15.8 \%)$. Moreover, the main compounds of Thuja orientalis L., were identified as $\alpha$-pinene $(34.1 \%), \alpha$-cedrol $(16.5 \%), \beta$-caryophyllene $(5.4 \%)$ and $\beta$-selinene (5.2\%). The chemotaxonomy implication of these results was also discussed.
\end{abstract}

Keywords: Cupressus tonkiensis; Sabina chinensis; Thuja orientalis; Bornyl Acetate; $\alpha$-Cedrol; $\alpha$-Pinene; Sabinene

\section{Introduction}

The genus Cupressus is one of several genera within the family Cupressaceae that has the common name cypress. It is considered a polyphyletic group. Based on genetic and morphological analysis, the Cupressus genus is found in the Cupressoideae subfamily [1]. As currently treated, these cypresses are native to scattered localities in mainly warm temperate regions in the Northern Hemisphere, including western North America, Central America, northwest Africa, the Middle East, the Himalayas, southern China and northern Vietnam [2]. Cupressus tonkinensis Silba., is an evergreen, medium-sized tree, up to 15 - 25 $\mathrm{cm}$ in height. Bark is grey brown with longitudinal fissures. Leaves are scaly, closely inserted on twigs. Cones are unisexual, grouped on a stalk. Male cone is subglobular. This is an endangered species in Vietnam, only found in a narrow area of the Central Region [3]. Little is known about the chemical constituents and biological potential of this plant. Leaves and stems of $C$. tonkinensis produce monoterpene-rich oils whose composition is $\alpha$-pinene (23.1\%), sabinene (21.0\%) and terpinen-4-ol $(14.4 \%)$ in the leaf while, $\alpha$-pinene $(42.5 \%)$, myrcene

\footnotetext{
"Corresponding author.
}

$(10.2 \%)$ and cedrol (9.0\%) were identified in the stem [4]. Another investigation identified sabinene (29.34\%), $\alpha$-pinene (25.4\%), 4-terpineol (13.91\%) and $\gamma$-terpinene (5.5\%) as major compounds of its leaf oil [3].

Sabina chinensis (L.) Antoine is an evergreen tree that grows up to $20 \mathrm{~m}$ high. The leaves are basal while the yellow flowers are unisexual [5]. S. chinensis is one of the important species used in Chinese garden and has a long history. It has many uses and more than 100 cultivars. The first report on the main constituents of $S$. chinensis identified sabinene (46.73\%), $\alpha$-pinene (17. 03\%), terpinen-4-ol (5.34\%) and limonene (4.48\%) as major constituents [6]. Another analysis [7] reported an abundance of $\alpha$-pinene $(21.1 \%)$, sabinene $(18.2 \%)$ and limonene $(9.2 \%)$ in the oil. Cui et al. [8] demonstrated that the main substances in volatile oil $S$. chinensis were bornyl acetate (38.1\%), $\alpha$-phellandrene (24.0\%) and $p$-menth-1-en-4-o1 (12.4\%). Another report [9] described the main composition of $S$. chinensis to be sabinene (20.99\%), limonene $(19.78 \%)$ and bornyl acetate (11.68\%).

The oil composition of two other species in the genus has been documented. The major compounds of $S$. virginiana [10] from Japan were limonene (32.9\%), safrole (23.0\%), asarone (15.9\%) and $\alpha$-pinene (5.2\%). S. chi- 
nensis cv. Kaizuca leaf oil, as reported by Cui et al. [10] contained bornyl acetate $(46.5 \%)$, limonene $(30.0 \%)$ and $\beta$-pinene $(7.9 \%)$, while limonene $(24.56 \%)$ and $\beta$-myrcene $(8.04 \%)$ are the prominent compounds from sample analysed by Hao et al. [9]. The volatile oil from S. chinensis had greater effects of bacteriostasis and air decontamination $[7,8,11]$. It is also indicated that constituents such as bornyl acetate, phellandrene, limonene and alphapinene and beta-pinene could also contribute to the antimicrobial activity of the volatile oils [11].

Thuja occidentalis (syn. Platycladus orientalis (L.) Franco or Biota orientalis (L.) Endl.) is an evergreen coniferous tree, in the cypress family Cupressaceae, which is native to the northeast of the United States and the southeast of Canada, but widely cultivated as an ornamental plant. T. occidentalis has fan-like branches and scaly leaves. It is only a small tree, growing to a height of $10-20 \mathrm{~m}$. The bark is red-brown, furrowed and peels in narrow, longitudinal strips. The cones are slender, yellow-green ripening brown, $10-15 \mathrm{~mm}$ broad, with $6-8$ overlapping scales. The branches may take root if the tree falls. Plants are susceptible to attacks by honey fungus [12]. Plants are monoecious, male catkins being produced at the tips of branches and female cones at the base [12]. The essential oil from the leaf of $P$. orientalis is an important natural product which is used in fragrance, air freshener, deodorizer, insectifuge, and aromatherapy.

The essential oil composition of the leaf of $T$. orientalis was investigated in Xuzhou, China [13], where its main components were $\alpha$-pinene (40.2\%), 3-carene (13.2\%), and cedrol (9.3\%). The data reported from Iran [14-16] showed that the main constituents were $\alpha$-pinene $(15.0 \%$ - 30.0\%), 3-carene $(10.5 \%$ - $21.7 \%)$, and cedrol $(6.1 \%$ $20.3 \%$ ). Previous studies in China [17-20] had revealed that the main constituents were $\alpha$-pinene $(8.4 \%-24.9 \%)$, 3 -carene $(2.6 \%-12.2 \%)$, and cedrol $(0.7 \%-31.4 \%)$. In a recent report [21], a population of $T$. orientalis afforded oils whose major compounds were $\alpha$-pinene $(37.6 \%$ $68.1 \%)$, cedrol $(3.4 \%-18.1 \%)$, 3-carene $(0.1 \%-29.4 \%)$, $\beta$-caryophyllene $(2.0 \%-10.2 \%)$ and $\alpha$-caryophyllene $(1.7 \%-7.1 \%)$ while a sample contained cedrol (15.0\%), 3 -carene $(12.2 \%)$ and $\beta$-caryophyllene $(8.0 \%)$, yet another sample had cedrol (19.2\%), $\beta$-caryophyllene (14.3\%) and $\alpha$-caryophyllene $(11.3 \%)$ while the last sample contained cedrol $(23.7 \%)$, terpinenyl acetate $(19.4 \%)$, 3-carene $(10.6 \%)$ and $\alpha$-pinene (10.2\%). $\alpha$ - and $\beta$-Thujone, fenchone, camphor and sabinene, as well as the diterpenes beyerene and rimuene were the main compounds in the work of Tsiri et al. [22] and Chizzola et al. [23]. In their own investigation, Guleria et al. [24] identified $\alpha$ pinene (29.2\%), $\delta$-3-carene (20.1\%), $\alpha$-cedrol (9.8\%), caryophyllene (7.5\%), $\alpha$-humulene $(5.6 \%)$ and limonene $(5.4 \%)$ in the oil of the plant. The dominant constituents in essential oil of $T$. orientalis from most localities are apinene, cedrol, and 3-carene. The previous studies also reveal a large variation in the essential oil composition of T. orientalis.

In the present paper, we report the essential oil compositions of three gymnosperms namely Cupressus tonkinensis Silba., Sabina chinensis (L.) Antoine and Thuja occidentalis L., from Vietnam. This is part of our extensive research on the volatile composition of Vietnamese flora as they are made available [25].

\section{Materials and Methods}

\subsection{Plants Collection}

Leaves of C. tonkiensis were collected from Huu Lien Natural reserve, Lang Son Province, Vietnam, in August 2010. The leaves of $S$. chinensis and T. orientalis were collected from Nghe An Province in August 2011. Voucher specimens DND 721, DND 194 and DND 196, respectively have been deposited at the Botany Museum, Vinh University, Vietnam. Plant samples were air-dried prior to extraction.

\subsection{Isolation of the Volatile Oils}

$0.5 \mathrm{~kg}$ of air-dried sample of each species was shredded and their oils obtained by hydrodistillation for $4 \mathrm{~h}$ at normal pressure, according to the Vietnamese Pharmacopoeia [26]. The plant samples yielded a low content of essential oils: $0.20 \%, 0.18 \%$ and $0.20 \%(\mathrm{v} / \mathrm{w}$; respectively for $C$. tonkiensis, $S$. chinensis and T. orientalis). Oil samples were light yellow colored.

\subsection{Gas Chromatography (GC) Analysis}

Gas chromatography (GC) analysis was performed on an Agilent Technologies HP 6890 Plus Gas chromatograph equipped with a FID and fitted with HP-Wax and HP5MS columns (both $30 \mathrm{~m} \times 0.25 \mathrm{~mm}$, film thickness 0.25 $\mu \mathrm{m}$, Agilent Technology). The analytical conditions were: carrier gas $\mathrm{H}_{2}(1 \mathrm{~mL} / \mathrm{min})$, injector temperature (PTV) $250^{\circ} \mathrm{C}$, detector temperature $260^{\circ} \mathrm{C}$, column temperature programmed from $40^{\circ} \mathrm{C}$ (2 min hold) to $220^{\circ} \mathrm{C}(10 \mathrm{~min}$ hold) at $4^{\circ} \mathrm{C} / \mathrm{min}$. Samples were injected by splitting and the split ratio was 10:1. The volume injected was $1.0 \mu \mathrm{L}$. Inlet pressure was $6.1 \mathrm{kPa}$.

\subsection{Gas Chromatography/Mass Spectrometry Analysis/(GC-MS)}

An Agilent Technologies HP 6890N Plus Chromatograph fitted with a fused silica capillary HP-5 MS column $(30 \mathrm{~m} \times 0.25 \mathrm{~mm}$, film thickness $0.25 \mu \mathrm{m})$ and interfaced with a mass spectrometer HP 5973 MSD was used for the GC/MS analysis, under the same conditions 
as those used for $\mathrm{GC}$ analysis. The conditions were the same as described above with $\mathrm{He}(1 \mathrm{~mL} / \mathrm{min})$ as carrier gas. The MS conditions were as follows: ionization voltage $70 \mathrm{eV}$; emission current $40 \mathrm{~mA}$; acquisitions scan mass range of $35-350 \mathrm{amu}$ at a sampling rate of $1.0 \mathrm{scan} / \mathrm{s}$.

\subsection{Identification of Constituents}

The identification of constituents was performed on the basis of retention indices (RI) determined by co-injection with reference to a homologous series of $n$-alkanes under identical experimental conditions. Further identification was performed by comparison of their mass spectra with those from NIST 08 Libraries (on ChemStation HP) and Wiley $9^{\text {th }}$ Version and the home-made MS library built up from pure substances and components of known essential oils, as well as by comparison of their retention indices with literature values [27,28].

\section{Results and Discussion}

The identities of compounds identified in the oil samples could be seen in Table 1. A total of 33 compounds were identified in the oil of $C$. tonkinensis, representing $94.0 \%$ of the oil content. The oil composed largely of monoterpenes $(50.1 \%)$ and sesquiterpenes $(40.7 \%)$ represented largely by $\alpha$-pinene (36.0\%) and $\alpha$-cedrol (18.3\%), along with minor quantities of thujopsene $(5.7 \%)$ and $\delta$-3-carene (3.1\%). Monoterpene compounds namely $\alpha$-pinene, sabinene, terpinen-4-ol and myrcene were the representa-

Table 1. Terpene composition of the oil samples.

\begin{tabular}{|c|c|c|c|c|c|}
\hline Compounds $^{\mathrm{a}}$ & $\mathbf{R I}^{\mathbf{b}}$ & $\mathbf{R I}^{\mathbf{c}}$ & C.p & S.c & T.o \\
\hline Butanoic acid & 802 & 763 & 3.1 & - & - \\
\hline Tricyclene & 927 & 921 & - & 0.5 & 0.2 \\
\hline$\alpha$-Thujene & 931 & 924 & - & 1.1 & - \\
\hline$\alpha$-Pinene & 939 & 932 & 36.0 & 15.8 & 34.1 \\
\hline Camphene & 953 & 946 & 0.8 & 0.8 & 0.8 \\
\hline Verbenene & 962 & 961 & - & - & 0.3 \\
\hline Sabinene & 976 & 969 & 0.6 & 17.3 & 1.2 \\
\hline$\beta$-Pinene & 980 & 974 & 1.8 & 0.6 & 3.1 \\
\hline$\beta$-Myrcene & 990 & 988 & 1.8 & 5.7 & 4.3 \\
\hline$\alpha$-Phellandrene & 1006 & 1002 & - & 0.1 & $\operatorname{Tr}$ \\
\hline$\delta$-3-Carene & 1013 & 1008 & 3.1 & - & 0.2 \\
\hline$\alpha$-Terpinene & 1016 & 1014 & - & 1.9 & 0.5 \\
\hline$p$-Cymene & 1024 & 1020 & 0.3 & 0.1 & 0.1 \\
\hline Limonene & 1032 & 1024 & - & 6.0 & 4.9 \\
\hline$(E)$ - $\beta$-Ocimene & 1052 & 1044 & - & $\operatorname{Tr}$ & 0.2 \\
\hline$\gamma$-Terpinene & 1061 & 1054 & - & 2.8 & 0.3 \\
\hline cis-Sabinene hydrate & 1070 & 1065 & - & 0.2 & - \\
\hline$\alpha$-Terpinolene & 1089 & 1086 & 0.4 & 1.5 & 3.7 \\
\hline Linalool & 1100 & 1095 & 1.0 & 0.2 & $\operatorname{Tr}$ \\
\hline$n$-Nonanal & 1106 & 1100 & - & - & $\operatorname{Tr}$ \\
\hline cis-p-Menth-2-en-1-ol & 1117 & 1118 & - & 0.2 & - \\
\hline allo-Ocimene & 1128 & 1128 & - & - & 0.1 \\
\hline trans-Pinocarveol & 1139 & 1135 & 0.5 & - & - \\
\hline Camphor & 1146 & 1141 & 0.6 & - & - \\
\hline Terpinen-4-ol & 1177 & 1174 & 1.0 & 1.6 & 0.1 \\
\hline Methyl chavicol & 1196 & 1195 & - & 0.4 & - \\
\hline Verbenone & 1205 & 1204 & 0.5 & - & - \\
\hline Carvacrol methyl ether & 1245 & 1241 & 1.7 & - & - \\
\hline Linalyl acetate & 1257 & 1254 & - & - & $\operatorname{Tr}$ \\
\hline 2-Decenal & 1259 & 1260 & - & - & $\operatorname{Tr}$ \\
\hline 1-Decanol & 1276 & 1266 & - & - & $\operatorname{Tr}$ \\
\hline Bornyl acetate & 1289 & 1287 & - & 19.5 & 0.7 \\
\hline Linalyl propanoate & 1335 & 1334 & - & $\operatorname{Tr}$ & $\operatorname{Tr}$ \\
\hline$\alpha$-Cubebene & 1351 & 1345 & 1.2 & - & - \\
\hline
\end{tabular}


Continued

\begin{tabular}{|c|c|c|c|c|c|}
\hline Neryl acetate & 1362 & 1359 & - & - & 0.1 \\
\hline$\alpha$-Ylangene & 1375 & 1373 & - & - & $\operatorname{Tr}$ \\
\hline$\alpha$-Copaene & 1377 & 1374 & - & 0.1 & 0.2 \\
\hline$\beta$-Bourbonene & 1385 & 1387 & - & $\operatorname{Tr}$ & 0.1 \\
\hline$\beta$-Elemene & 1397 & 1398 & 1.4 & 0.1 & 0.3 \\
\hline Methyl eugenol & 1407 & 1410 & - & 0.3 & - \\
\hline$\alpha$-Cedrene & 1409 & 1410 & - & - & 0.3 \\
\hline$\alpha$-Gurjunene & 1410 & 1409 & 0.6 & - & - \\
\hline$\beta$-Caryophyllene & 1419 & 1417 & 0.6 & - & 5.4 \\
\hline cis-Thujopsene & 1431 & 1429 & 5.7 & - & - \\
\hline$\beta$-Gurjunene & 1434 & 1431 & - & 0.1 & - \\
\hline$\alpha$-Guaiene & 1440 & 1437 & 1.0 & - & - \\
\hline Aromadendrene & 1441 & 1439 & - & - & 0.6 \\
\hline Widdrene & 1444 & - & - & - & 0.3 \\
\hline$\alpha$-Humulene & 1454 & 1452 & 0.6 & - & - \\
\hline trans- $\beta$-Farnesene & 1455 & 1454 & - & - & 0.1 \\
\hline allo-Aromadendrene & 1460 & 1458 & - & - & 0.2 \\
\hline$\beta$-Acoradiene & 1470 & 1469 & - & - & 0.2 \\
\hline ar-Curcumene & 1475 & 1479 & - & - & 0.1 \\
\hline$\gamma$-Gurjunene & 1477 & 1475 & - & 0.1 & - \\
\hline$\gamma$-Muurolene & 1480 & 1478 & 0.8 & - & - \\
\hline Germacrene D & 1485 & 1484 & - & 0.7 & 0.9 \\
\hline$\alpha$-Amorphene & 1486 & 1483 & - & $\operatorname{Tr}$ & 0.8 \\
\hline$\beta$-Selinene & 1490 & 1489 & - & - & 5.2 \\
\hline Zingiberene & 1494 & 1493 & 1.8 & - & 1.6 \\
\hline cis-Cadina-1,4-diene & 1496 & 1495 & 1.1 & - & 0.3 \\
\hline$\alpha$-Selinene & 1498 & 1498 & - & - & 0.5 \\
\hline$\alpha$-Muurolene & 1500 & 1500 & - & 0.2 & 0.2 \\
\hline$\gamma$-Patchoulene & 1502 & 1502 & - & - & 0.1 \\
\hline Lepidozene & 1502 & - & - & - & 0.2 \\
\hline Cuparene & 1505 & 1504 & 2.2 & - & - \\
\hline$\beta$-Bisabolene & 1506 & 1505 & - & - & 0.3 \\
\hline$(E, E)-\alpha$-Farnesene & 1506 & 1505 & 0.9 & - & - \\
\hline$\gamma$-Cadinene & 1514 & 1513 & - & 0.1 & 0.3 \\
\hline trans- $\gamma$-Bisabolene & 1517 & 1514 & - & - & 0.1 \\
\hline$\delta$-Cadinene & 1525 & 1522 & 2.1 & 0.6 & 0.7 \\
\hline Elemol & 1550 & 1548 & 0.6 & 6.4 & 0.1 \\
\hline 3-Hexen-1-ol, benzoate & 1551 & - & - & 0.1 & 0.2 \\
\hline Dodecanoic acid & 1567 & 1565 & - & - & $\operatorname{Tr}$ \\
\hline Germacrene-D-4-ol & 1574 & 1574 & - & - & 0.2 \\
\hline Spathulenol & 1579 & 1577 & - & - & 1.3 \\
\hline Caryophyllene oxide & 1583 & 1582 & - & 0.1 & 1.6 \\
\hline$\alpha$-Cedrol & 1601 & 1600 & 18.3 & - & 26.5 \\
\hline$\beta$-Oplopenone & 1608 & 1607 & - & 0.4 & - \\
\hline Tetradecanal & 1611 & 1611 & - & - & $\operatorname{Tr}$ \\
\hline$\gamma$-Eudesmol & 1632 & 1630 & - & 0.4 & - \\
\hline$\tau$-Muurolol & 1646 & 1640 & 1.6 & 1.5 & 0.3 \\
\hline$\beta$-Eudesmol & 1651 & 1649 & 0.7 & - & - \\
\hline$\alpha$-Cadinol & 1654 & 1652 & - & - & 0.5 \\
\hline$\alpha$-Bisabolol & 1686 & 1685 & 0.4 & - & - \\
\hline
\end{tabular}




\begin{tabular}{|c|c|c|c|c|c|}
\hline \multicolumn{6}{|l|}{ Continued } \\
\hline Franesol $^{\mathrm{d}}$ & 1718 & - & - & - & 0.1 \\
\hline Benzyl benzoate & 1760 & 1759 & - & $\operatorname{Tr}$ & - \\
\hline Tetradecanoic acid & 1770 & - & - & - & $-\operatorname{Tr}$ \\
\hline 1,2-Benzenedicarboxylic acid & 1917 & 1917 & - & 1.0 & 2.9 \\
\hline 16-Hexadecanolide & 1928 & - & - & - & 0.2 \\
\hline ent-Pimara-8(14),15-diene & 1939 & - & - & 0.3 & - \\
\hline Hexadecanoic acid & 1970 & 1959 & - & $\operatorname{Tr}$ & $\operatorname{Tr}$ \\
\hline Abietatriene & 2050 & 2055 & - & 0.7 & 0.2 \\
\hline Phytol & 2125 & 1942 & - & - & $\operatorname{Tr}$ \\
\hline Totarol & 2314 & 2314 & - & 0.1 & - \\
\hline cis-Ferruginol & 2371 & 2370 & - & 0.1 & 0.1 \\
\hline (Z)-9-Octadecenamide & 2398 & 2396 & - & - & 0.1 \\
\hline \multicolumn{3}{|c|}{ Total } & 94.0 & 90.0 & 98.4 \\
\hline \multicolumn{3}{|c|}{ Monoterpene hydrocarbons } & 44.8 & 53.6 & 54.2 \\
\hline \multicolumn{3}{|c|}{ Oxygenated monoterpenes } & 5.3 & 23.5 & 0.9 \\
\hline \multicolumn{3}{|c|}{ Sesquiterpene hydrocarbons } & 20.0 & 2.0 & 19.2 \\
\hline \multicolumn{3}{|c|}{ Oxygenated sesquiterpenes } & 20.7 & 8.8 & 20.6 \\
\hline \multicolumn{3}{|c|}{ Diterpenes } & - & 1.2 & 0.1 \\
\hline \multicolumn{3}{|c|}{ Non-terpenes } & 3.1 & 1.1 & 3.4 \\
\hline
\end{tabular}

${ }^{\mathrm{a}}$ Elution order on HP-5MS capillary column; ${ }^{\mathrm{b}}$ Retention indices on HP-5MS capillary column; ${ }^{\mathrm{c}}$ Literature Retention indices (see Experimental); ${ }^{\mathrm{d}}$ Correct isomer not identified; - Not identified and not present in Literature; Tr, Trace amount, $<0.1 \% ;$ C. $p=$ Cupressus tonkinensis; $S . c=$ Sabina chinensis; T. $o=$ Thuja orientalis.

tive compounds of previous studies on C. tonkinensis [3, 4]. The $\alpha$-pinene content of this oil competes favourably with previous studies while the contents of other monoterpenes above are significantly lower. Cedrol was previously present in the stem oil but not in the leaf [4].

A total of 45 compounds could be identified from the leaf oil of $S$. chinensis, representing $90.0 \%$ of the oil content. Also, monoterpenoids (77.1\%) were in abundance in the oil. The major constituents among the monoterpenes were bornyl acetate (19.5\%), sabinene (17.3\%) and $\alpha$-pinene $(15.8 \%)$. The large amount of $\alpha$-pinene and sabinene is in agreement with previous reports [6-9], but differs from its lower contents of tricyclene, $\beta$-myrcene, $\alpha$-phellandrene, limonene and $p$-menth-1-en-4-o1. Sesquiterpenes are less common (10.8\%) represents mainly by elemol $(6.4 \%)$ and $\tau$-muurolol $(1.5 \%)$ as compounds above $1 \%$. There seems to be homogeneity in the oil composition of $S$. chinensis. Bornyl acetate was among the main compounds of $S$. chinensis cv. Kaizuca [10]. Limonene is a common compound of the oil of the genus Sabina [6-10].

Monoterpenes (55.1\%) and sesquiterpenes (39.8\%) are classes of compounds identified in the 69 constituents of the oil of $T$. orientalis. The main compounds were $\alpha$ pinene $(34.1 \%)$ and $\alpha$-cedrol (16.5\%). Other significant compounds were $\beta$-caryophyllene $(5.4 \%), \beta$-selinene (5.2\%), limonene $(4.9 \%)$ and $\alpha$-terpinene $(3.7 \%)$. The predominant compounds were $\alpha$-pinene and cedrol. This result was similar to those previously reported [13-21,24, 29,30-32], which revealed that the main constituents were a-pinene $(15.0 \%-68.1 \%)$, cedrol $(3.4 \%-39.06 \%)$ and 3 -carene $(0.1 \%-34.55 \%)$. However, the content of 3 -carene in this sample is too low when compared with previous studies (Table 2). Other compounds such as $\beta$ caryophyllene, $\alpha$-caryophyllene and terpinenyl acetate [21], $\alpha$-and $\beta$-thujone, fenchone, sabinene, camphor, beyerene and rimuene [22,23], fenchol and $\beta$-santalene [32] and cedrene [19], that are characteristics of previous reports are either observed in low amounts (e.g. $\delta$-3-carene, sabinene) or completely absent (e.g. $\alpha$ - and $\beta$-thujone, fenchone, fenchol, terpinenyl acetate, $\beta$-santalene, $\alpha$-caryophyllene, cedrene, beyerene and rimuene) in this present study (Tables 1 and 2).

The previous studies also revealed a large variation in the essential oil composition of $T$. orientalis. Therefore, the oils of $T$. orientalis could be classified as follows:

1) group characterized by a predominant $\alpha$-pinene, $\delta$ 3 -carene and cedrol [13-18,20,21,24,29 and this study]

2 ) group dominated by cedrol, $\delta$-3-carene and $\beta$-caryophyllene [21]

3 ) group with contents of cedrol, $\beta$-caryophyllene and $\alpha$-caryophyllene

4) $\alpha$-pinene, $\delta$-3-carene and sabinene group [14]

5) $\alpha$-thujone, $\beta$-thujone and fenchone rich oil [22] 
Table 2. Major constituents of essential oils of $T$. orientalis.

\begin{tabular}{|c|c|c|}
\hline Origin & Major Constituents & Ref \\
\hline Vietnam (1) & $\begin{array}{l}\alpha \text {-cedrol }(16.5 \%), \alpha \text {-pinene }(34.1 \%), \beta \text {-caryophyllene } \\
(5.4 \%) \text { and } \beta \text {-selinene }(5.2 \%)\end{array}$ & This study \\
\hline China (1) & $\alpha$-pinene (40.2\%), 3-carene (13.2\%) and cedrol (9.3\%) & 13 \\
\hline $\operatorname{Iran}(w)$ & $\alpha$-pinene (15.0\%), 3-carene (10.5\%) and cedrol (20.3\%) & 14 \\
\hline $\operatorname{Iran}(1)$ & $\begin{array}{l}\alpha \text {-pinene }(15.2 \%), 3 \text {-carene }(12.0 \%), \text { cedrol }(11.7 \%) \text { and } \\
\text { sabinene }(10.0 \%)\end{array}$ & 14 \\
\hline $\operatorname{Iran}(f)$ & $\alpha$-pinene $(23.5 \%), 3$-carene $(23.8 \%)$ and sabinene $(11.1 \%)$ & 14 \\
\hline $\operatorname{Iran}(1)$ & $\begin{array}{l}\alpha \text {-pinene }(21.9 \%), \alpha \text {-cedrol }(20.3 \%), \delta \text {-3-carene }(10.5 \%) \\
\text { and limonene }(7.2 \%)\end{array}$ & 15 \\
\hline $\operatorname{Iran}(f)$ & $\begin{array}{l}\alpha \text {-pinene }(52.4 \%), \delta \text {-3-carene }(14.2 \%), \alpha \text {-cedrol }(6.5 \%) \text { and } \\
\beta \text {-phellandrene }(5.1 \%)\end{array}$ & 15 \\
\hline $\operatorname{Iran}(1)$ & $\begin{array}{l}\alpha \text {-pinene }(30.0 \%), \delta \text {-3-carene }(21.7 \%), \beta \text {-caryophyllene } \\
(6.9 \%) \text {, and cedrol }(6.1 \%)\end{array}$ & 16 \\
\hline $\operatorname{Iran}(\mathrm{st})$ & $\begin{array}{l}\delta \text {-3-carene }(24.3 \%), \alpha \text {-pinene }(15.4 \%) \text {, cedrol }(17.7 \%) \text {, } \\
\text { sabinene }(8.2 \%), \alpha \text {-humulene }(6.1 \%)\end{array}$ & 16 \\
\hline $\operatorname{Iran}(\mathrm{f})$ & $\begin{array}{l}\alpha \text {-pinene }(38.7 \%), \delta \text {-3-carene }(20.4 \%) \text { and } \alpha \text {-fenchene } \\
(5.0 \%)\end{array}$ & 16 \\
\hline China (1) & $\alpha$-pinene (8.4\%), 3-carene (12.2\%) and cedrol (10.7\%) & 17 \\
\hline China $(1 / \mathrm{tw})$ & cedrol $(30 \%)$ and $\alpha$ pinene $(5 \%)$ & 18 \\
\hline China (1) & cedrene $(41.25 \%)$, cedrol (39.06\%), cedrol (31.43\%) & 19 \\
\hline China (1) & $\alpha$-pinene (24.9\%), 3-carene (2.6\%) and cedrol (12.7\%) & 20 \\
\hline China (1) & $\begin{array}{l}\alpha \text {-pinene }(37.6 \%-68.1 \%) \text {, cedrol }(3.4 \%-18.1 \%), 3 \text {-carene } \\
(0.1 \%-29.4 \%), \beta \text {-caryophyllene }(2.0 \%-10.2 \%) \text { and } \\
\alpha \text {-caryophyllene }(1.7 \%-7.1 \%)\end{array}$ & 21 \\
\hline China (1) & $\begin{array}{l}\text { cedrol }(15.0 \%), 3 \text {-carene }(12.2 \%) \text { and } \beta \text {-caryophyllene } \\
(8.0 \%)\end{array}$ & 21 \\
\hline China (1) & $\begin{array}{l}\text { cedrol }(19.2 \%), \beta \text {-caryophyllene }(14.3 \%) \text { and } \\
\alpha \text {-caryophyllene }(11.3 \%)\end{array}$ & 21 \\
\hline China (1) & $\begin{array}{l}\text { cedrol }(23.7 \%) \text {, terpinenyl acetate }(19.4 \%), 3 \text {-carene } \\
(10.6 \%) \text { and } \alpha \text {-pinene }(10.2 \%)\end{array}$ & 21 \\
\hline Poland & $\begin{array}{l}\alpha \text { - and } \beta \text {-thujone, fenchone, sabinene, beyerene and } \\
\text { rimuene }^{\mathrm{a}}\end{array}$ & 22 \\
\hline Austria (tw) & $\begin{array}{l}\text { camphor }(27.8 \%) \text {, fenchone }(18.9 \%), \alpha \text {-thujone }(6.8 \%) \text { and } \\
\beta \text {-thujone }(5.3 \%)\end{array}$ & 23 \\
\hline China (1) & $\begin{array}{l}\alpha \text {-pinene }(29.2 \%), \delta \text {-3-carene }(20.1 \%), \alpha \text {-cedrol }(9.8 \%), \\
\text { caryophyllene }(7.5 \%), \alpha \text {-humulene }(5.6 \%) \text { and limonene } \\
(5.4 \%)\end{array}$ & 24 \\
\hline Pakistan (1) & $\alpha$-pinene (40.6\%), 3-carene (26.0\%) and cedrol $(10.7 \%)$ & 29 \\
\hline Pakistan (f) & $\begin{array}{l}\alpha \text {-pinene }(41.8 \%-45.61 \%), 3 \text {-carene }(32.69 \%-34.55 \%) \\
\text { and cedrol }(1.82 \%-4.50 \%)\end{array}$ & 30 \\
\hline $\operatorname{Iran}(\mathrm{dp})$ & $\alpha$-pinene, $\beta$-pinene, sabinene, $\delta$-3-carene and terpinolene ${ }^{\mathrm{a}}$ & 31 \\
\hline Nigeria (l) & $\begin{array}{l}\beta \text {-santalene }(12.19 \%) \text {, cedrol }(11.66 \%) \text {, fenchol }(10.66 \%) \\
\text { and } \beta \text {-elemene }(7.81 \%)\end{array}$ & 32 \\
\hline
\end{tabular}

${ }^{\mathrm{a}}$ Quantitative data not available; $1=$ leaf; $\mathrm{f}=$ fruit; $\mathrm{st}=$ stem; $\mathrm{dp}=$ different parts; $\mathrm{tw}=$ twig.

6) camphor, fenchone and $\alpha$-thujone group [23]

7) $\alpha$-pinene, $\beta$-pinene and sabinene group [31]

\section{Conclusion}

Quantitative and qualitative variations were observed between these oils of Cupressaceae family cultivated in Vi- etnam and elsewhere. This may be attributed to factors such as the place of collection, age and nature of the plant, climatic conditions, handling procedures etc.

\section{Acknowledgements}

Authors are grateful to Mrs. Ogunwande Musilimat for 
the typesetting of the manuscript.

\section{REFERENCES}

[1] J. Silba, "The Trans-Pacific Relationship of Cupressus in India and North America," Journal of the International Conifer Preservation Society, Vol. 1, No. 1, 1994, pp. 2325.

[2] K. Rushforth, "Notes on the Cupressaceae in Vietnam," Vietnam Journal of Biology, Vol. 29, No. 1, 2007, pp. 3239.

[3] T. H. Thai, N. T. Hien, D. T. Minh and P. V. The, "The Chemical Composition of Leaf Oil of Cupressus tonkinensis Silba. in Huu Lien, Lang Son Province," Vietnam Journal of Biology, Vol. 31, No. 1, 2009, pp. 74-79.

[4] T. H. Thai, O. Bazzali, N. T. Hien, P. V. The, P. K. Loc, T. M. Hoi, F. Tomi, J. Casanova and A. Bighelli, "Chemical Composition of Leaf and Stem Oils from Vietnamese Cupressus tonkinensis Silba," Journal of Essential Oil Research, Vol. 25, No. 1, 2013, pp. 11-16. http://dx.doi.org/10.1080/10412905.2012.751056

[5] Y. Zhang and J. Ming, "Classification of Sabina chinensis (Linn.) Ant. Cultivars," Journal of Hubei Agricultural College, Vol. 21, No. 1, 2001, pp. 25-28.

[6] H. Y. Zilian, "Constituents of the Essential Oils from $\mathrm{Sa}$ bina chinensis," Natural Product Research and Development, Vol. 6, No. 1, 1990, pp. 36-39.

[7] Y. Gao, Y.-J. Jin, H.-D. Li and H.-J. Chen, "Volatile Organic Compounds and Their Roles in Bacteriostasis in Five Conifer Species," Journal of Integrative Plant Biology, Vol. 47, No. 4, 2005, pp. 499-507.

http://dx.doi.org/10.1111/j.1744-7909.2005.00081.x

[8] Y.-Q. Cui, P. Nan and M.-H. Lin, "Main Volatile Components in the Leaves of Sabina chinensis L. Ant. and Sabina chinensis L. Ant. cv. Kaizuca and Their Effects on Bacteria," Journal of Environment and Health, Vol. 21, No. 3, 2006. http://www.shvoong.com/medicine-and-health/1611504main-volatile-components-leaves-sabina/\#ixzz2RyT5s1G7

[9] D. Hao, Y. Zhang, H. Dai and Y. Wang, "Analysis of Volatile Constituents in Leaves of Three Cypress Species by Gas Chromatography/Mass Spectrometry," Chinese Journal of Chromatography, Vol. 24, No. 2, 2006, pp. 185187.

[10] S. A. Aboaba, I. A. Oladosu and I. A. Ogunwande, "Topical Anti-Inflammatory and Chemical Composition of Essential Oil of Sabina virginiana L. Antoine (Cupressaceae)," Archives of Applied Science Research, Vol. 2, No. 2, 2010, pp. 1-6.

[11] Y.-Q. Cui, X.-H. Cui, Y. Zhu, Q. Zhang and P. Nan, "Chemical Composition and Antimicrobial Activity of Volatile Oil of Six Gymnosperm Species Leaves from Shanghai," The 2nd International Conference on Bioinformatics and Biomedical Engineering (ICBBE), 2008, pp. 4573-4577. http://dx.doi.org/10.1109/ICBBE.2008.303

[12] V. D. Nguyen and T. N. Doan, "Medicinal Plants in Vietnam," Hanoi Publishing House, Hanoi, 2006, p. 234.

[13] Y. D. Chen, S. X. Li, L. Yang, Z. Y. Jiang and N. H. Cui,
"Comparative Study on Chemical Constituents of Essential Oils from several parts of Platycladus orientlais," Chemical Industry and Forest, Vol. 1, No. 1, 1984, pp. 111.

[14] M. K. Hassanzadeh, M. Rahimizadeh, B. S. Fazly Bazzaz, S. A. Emami and J. Assili, "Chemical and Antimicrobial Studies of Platycladus Orientalis Essential Oils," Pharmaceutical Biology, Vol. 39, No. 5, 2001, pp. 388-390. http://dx.doi.org/10.1076/phbi.39.5.388.5894

[15] B. Nickavar, G. Amin and S. Parhami, "Volatile Constituents of the Fruit and Leaf Oils of Thuja orientalis L. grown in Iran," Z Naturforsch C, Vol. 58, No. 3-4, 2003, pp. 171-172.

[16] S. Afsharypuor and B. Nayebzadeh, "Essential Oil Constituents of Young Stem, Leaf and Fruit of Platycladus orientalis (L.) Franco Grown in Isfahan (Iran)," Journal of Essential Oil Research, Vol. 21, No. 6, 2009, pp. 525528. http://dx.doi.org/10.1080/10412905.2009.9700235

[17] T. L. Liu, Q. Qiu, Y. Zhao, Y. M. Shen and J. Wang, "Study on Chemical Constituents of Essential Oil of Biota orientlais by GC-MS," Journal of Chinese Medicinal Materials, Vol. 23, No. 10, 2000, pp. 460-461.

[18] G. Wei and S. Y. Wang, "The GC-MS Analysis for Volatile Constituents in Leaf/Twigs of Chinese Arborvitae," Lishizhen Medicinal Materia Medica Research, Vol. 12, No. 1, 2001, pp. 18-19.

[19] R. H. Hui, D. Y. Hou, X. Y. Liu, X. C. Li and H. L. Geng, "Analysis of Volatile Components from Leaf Twigs in Biota orientalis with Different Extraction Methods by Gas Chromatography-Mass Spectrometry," Journal of Chinese Mass Spectrometry Society, Vol. 27, No. 3, 2006, pp. 226-231.

[20] P. Li, L. S. Wang and H. Tang, "Determination of Chemical Constituents of the Essential Oil from Cacumen Platycladi in Xinjiang by GC-MS," Lishizhen Medicinal Materia Medica Research, Vol. 17, No. 12, 2006, pp. 951-957.

[21] H. Lei, Y. Wang, F. Liang, W. Su, Y. Feng, X. Guo and N. Wang, "Composition and Variability of Essential Oils of Platycladus orientalis Growing in China," Biological and Systematic Ecology, Vol. 38, No. 9, 2010, pp. 10001006. http://dx.doi.org/10.1016/j.bse.2010.09.018

[22] D. Tsiri, K. Graikou, L. Pobłocka-Olech, M. Krauze-Baranowska, C. Spyropoulos and I. Chinou "Chemosystematic Value of the Essential Oil Composition of Thuja Species Cultivated in Poland-Antimicrobial Activity," Molecules, Vol. 19, No. 14, 2009, pp. 4707-4715.

[23] R. Chizzola, W. Hochsteiner and S. Hajek, "GC Analysis of Essential Oils in the Rumen Fluid after Incubation of Thuja orientalis Twigs in the Rusitec System," Research in Veterinary Science, Vol. 76, No. 1, 2004, pp. 77-82. http://dx.doi.org/10.1016/j.rvsc.2003.07.001

[24] S. Guleria, A. Kumar and A. K. Tiku, "Chemical Composition and Fungitoxic Activity of Essential Oil of Thuja orientalis L. Grown in the North-Western Himalaya," Zeit Naturforsch C, Vol. 63, No. 3-4, 2008, pp. 211-214.

[25] D. N. Dai, T. D. Thang, L. T. M. Chau and I. A. Ogunwande, "Chemical Constituents of the Root Essential Oils of Zingiber rubens and Zingiber zerumbet," American Journal of Plant Sciences, Vol. 4, No. 1, 2013, pp. 7-10. 
http://dx.doi.org/10.4236/ajps.2013.41002

[26] "Vietnamese Pharmacopoeia," Medical Publishing House, Hanoi, 1997, p. 89.

[27] R. P. Adams, "Identification of Essential Oil Components by Gas Chromatography/Quadrupole Mass Spectrometry," 4th Edition, Allured Publishing, Carol Stream, 2007.

[28] D. Joulain and W. A. Koenig, "The Atlas of Spectral Data of Sesquiterpene,” E. B. Verlag, Hamburg, 1998.

[29] M. Riaz, M. K. Rashid and F. M. Chaudary, "Volatile Constituents of the Leaves Pakistani Cumpressus sempervirens and Thuja orientalis," Pakistan Journal of Science and Industrial Research, Vol. 42, No. 2, 1999, pp. 98-101.

[30] M. Riaz, S. Qamar, M. K. Rashid and F. M. Chaudary,
"Chemical Composition of Thuja orientalis L. Fruits at Different Stages of Maturity," Pakistan Journal of Science and Industrial Research, Vol. 42, No. 4, 1999, pp. 188-191.

[31] I. A. Ogunwande, N. O. Olawore, K. A. Adeleke and O. Ekundayo, "Composition of the Volatile Oil of Thuja orientalis L. from Nigeria," Journal of Tropical Forest Resources, Vol. 19, No. 2, 2003, pp. 41-47.

[32] S. A. Emami, J. Asili, M. Malekian and M. K. Hassanzade, "Antioxidant Effects of the Essential Oils of Different Parts of Platycladus orientalis L. (Franco) and Their Components," Journal of Essential Oil Bearing Plants, Vol. 14, No. 3, 2011, pp. 103-107.

http://dx.doi.org/10.1080/0972060X.2011.10643943 